\title{
PEMERINTAH DAN HAK BERAGAMA DI INDONESIA (Peran Pemerintah Dalam Memelihara Hak Beragama Di Indonesia)
}

\author{
Irfan Setia Permana \\ Teknik Informatika, Politeknik TEDC Bandung
}

\begin{abstract}
Abstrak
Pemerintah dalam hal ini adalah lembaga legislatif dan eksekutif merupakan pengelola dalam tatanan sebuah Negara. Kondusifnya sebuah Negara bergantung dari peran pemerintah dalam memperlakukan setiap warganya dengan adil. Salah satu yang menjadi perhatian Negara tentunya adalah Agama. Terdapat enam Agama yang diakui sebagai Agama resmi di Indonesia. Oleh sebab itu maka pemeluk suatu agama di Indonesia selayaknya diperlakukan secara proporsional dan adil oleh Pemerintah sehingga dapat menjalankan kewajiban agamanya. Dalam pembahasan ini metode yang digunakan adalah dengan pendekatan analisis deskriptif. Adapun langkah-langkah yang dilakukan dalam pembahasan tema ini adalah: menentukan fokus penelitian, menentukan jenis dan sumber data kemudian mengolah dan menganalisisnya. Hasil dari pembahasan topik ini menunjukkan bahwa Undang-undang Negara Indonesia telah menjamin hak dan kebebasan setiap warganya untuk beragama sesuai keyakinannya sendiri. Oleh karena itu, maka selayaknyalah orang-orang yang duduk di legislatif dan eksekutif untuk senantiasa menjaga kebebasan beragama setiap warganya tersebut tanpa melihat ideologi yang dianutnya. Masih terdapat di negeri ini praktik-praktik diskriminatif dan ketidakadilan terhadap pemeluk agama tertentu, maka diperlukan langkahlangkah untuk memberikan keadilan bersama, diantaranya; perjuangan politik kesetaraan dan penguatan kapasitas dan pemahaman multikulturalisme atas nilai-nilai demokrasi. Upaya pertama merupakan advokasi atas sejumlah kebijakan negara yang masih dirasa belum adil. Beberapa produk undang-undang yang kurang selaras dengan semangat UUD 1945 dan perkembangan dunia modern sudah selayahnya ditinjau kembali. Sedangkan upaya kedua dimaksudkan untuk memperkuat kesadaran umat mayoritas untuk lebih mengembangkan nilai-nilai kesetaraan, kebebasan, humanistik, cinta tanah air dan toleransi terhadap keragaman. Apabila hal-hal mulia ini berhasil dikembangkan dan diimplementasikan oleh seluruh umat maka akan bermanfaat tidak hanya bagi konsolidasi demokrasi di negeri ini, tetapi juga akan semakin meneguhkan bangsa dan Negara.
\end{abstract}

Kata Kunci: pemerintah, agama

\begin{abstract}
The government in this case is the legislative and executive institutions are managers in the order of a State. The condusiveness of a State depends on the government's role in treating every citizen fairly. One of the concerns of the State is of course Religion. There are six Religions recognized as official Religion in Indonesia. Therefore, the adherents of a religion in Indonesia should be treated proportionally and fairly by the Government so that it can perform its religious duties. In this discussion the method used is descriptive analysis approach. The steps taken in the discussion of this theme are: determine the focus of research, determine the type and source of data then process and analyze it. The result of the discussion of this topic shows that the Law of the State of Indonesia has guaranteed the right and freedom of every citizen to religion according to his own belief. Therefore, it is appropriate that the people who sit in the legislature and the executive to always maintain the religious freedom of every citizen without looking at the ideology he embraces. There is still in this country discriminatory practices and injustices against the adherents of certain religions, it is necessary steps to provide justice together, including; political struggle for equality and capacity building and understanding of multiculturalism over democratic values. The first attempt was an advocacy of a number of state policies that were still considered unfair. Some legislation products that are less in harmony with the spirit of the 1945 Constitution and the development of the modern world are now being reviewed. While the second attempt is intended to strengthen the consciousness of the majority to further develop the values of equality, freedom, humanistic, homeland love and tolerance to diversity. If these noble things are successfully developed and implemented by all people it will be useful not only for the consolidation of democracy in this country, but also to strengthen nation and State.
\end{abstract}

Keywords: government, religion

\section{PENDAHULUAN}

Indonesia merupakan negara yang sangat besar yang didalamnya terdapat berbagai Agama dan suku dengan agama terbesarnya yaitu Islam dan suku terbesarnya adalah suku jawa. Indonesia juga dinilai sebagai negara berpenduduk mayoritas muslim terbesar di dunia dan yang sukses mengembangkan demokrasi. Namun di sisi lain, sejumlah perlakuan diskriminatif atas kaum minoritas masih terlihat di negeri ini. Kaum minoritas belum sepenuhnya memperoleh hak mereka terutama terkait dengan kebebasan beragama dan berkeyakinan. Tulisan ini berusaha memetakan relasi antara kaum mayoritas muslim 
dan minoritas non-Muslim di Indonesia yang melibatkan dua hal penting: Kesiapan kultur mayoritas sebagai subyek utama dan konstitusi negara. Berbagai tindak pelanggaran HAM dan perlakuan diskriminatif yang dialami minoritas ternyata tidak hanya dilakukan oleh kelompok mayoritas semata, tetapi juga oleh negara.

Negara secara sistemastis telah mengeluarkan sejumlah produk perundang-undangan yang potensial meminggirkan kelompok tertentu dan lebih berpihak kepada mayoritas. Oleh sebab itu, untuk melindungi hak-hak warga negara oleh gangguan kelompok tertentu, maka tulisan ini memfokuskan pada peran Negara terhadap kebebasan beragama di Indonesia. Hal ini dimaksudkan untuk mendorong negara lebih serius memperhatikan dan melindungi hak dan kebebasan beragama setiap warga negara dengan menerbitkan undang-undang dan regulasi yang adil dan mengayomi semua. Sementara tujuan dari tulisan ini adalah untuk memberikan pemahaman dan memperkuat nilai-nilai demokrasi seperti kebebasan, kesetaraan dan toleransi yang sesungguhnya telah ada dalam diri semua warga negara.

\section{Undang-Undang Tentang Beragama}

Negara telah menjamin kebebasan beragama bukan baru-baru ini, melainkan sejak Negara ini merdeka melalui undang-undang. Diantara undang-undang tersebut yaitu Undang-Undang Dasar Negara Republik Indonesia Tahun 1945 BAB XA Pasal 28E Tentang hak asasi manusia; (1) Setiap orang berhak memeluk agama dan beribadat menurut agamanya, memilih pendidikan dan pengajaran, memilih pekerjaan, memilih kewarganegaraan, memilih tempat tinggal di wilayah negara dan meninggalkannya, serta berhak kembali. (2) Setiap orang berhak atas kebebasan meyakini kepercayaan, menyatakan pikiran dan sikap, sesuai dengan hati nuraninya.

Dalam pasal 28I ayat 1 disebutkan bahwa hak untuk hidup, hak untuk tidak disiksa, hak untuk kemerdekaan pikiran dan hati nurani, hak beragama, hak untuk tidak diperbudak, hak untuk diakui sebagai pribadi dihadapan hukum, dan hak untuk tidak dituntut atas dasar hukum yang berlaku surut adalah hak asasi manusia yang tidak dapat dikurangi dalam keadaan apapun.

Sedangkan dalam bab XI pasal 29 tentang Agama disebutkan; (1) Negara berdasar atas Ketuhanan Yang Maha Esa. (2) Negara menjamin kemerdekaan tiap-tiap penduduk untuk memeluk agamanya masing-masing dan untuk beribadat menurut agamanya dan kepercayaannya itu.

Dari beberapa undang-undang tersebut jelaslah bahwa kebebasan bagi setiap warga Negara dilindungi oleh Negara. Oleh karena itu, maka pemaksaan dan diskriminasi terhadap kelompok tertentu tidak dibenarkan sesuai hukum yang berlaku tersebut.

\section{METODOLOGI PENELITIAN}

Dalam pembahasan topik ini, langkahlangkahyang dilakukan adalah sebagai berikut:

1. Metode

Dalam pembahasan topik ini menggunakan pendekatan kualitatif deskriptif, yaitu suatu yang temuan-temuannya tidak diperoleh melalui prosedur statistik atau bentuk hitungan lainnya. Penelitian kualitatif melakukan penelitian pada latar alamiah atau pada konteks dari suatu keutuhan (entity), hal ini dilakukan karena ontology alamiah menghendaki adanya kenyataan-kenyataan sebagai keutuhan yang tidak dapat dipahami jika dipisahkan dari konteksnya.

2. Jenis data

Data dalam pembahasan topik ini didapat dari undang-undang yang berkaitan tentang hak beragama dan dari pemeluk berbagai agama di Indonesia.

3. Teknik pengumpulan data

Data penelitian yang digunakan dalam penelitian ini dikumpulkan dengan menggunakan teknik pengamatan pada undang-undang dan insan beragama

4. Kesimpulan

Data yang sudah dikumpulkan kemudian disusun secara sistematis dan kemudian disimpulkan. Menyimpulkan dari data yang ada dilakukan untuk menemukan makna yang dimaksud. Untuk mendapatkan kesimpulan yang lebih mendalam dan lebih fokus maka dilakukan penelitian terhadap data lain yang baru dicari dan ditemukan untuk diuji terhadap berbagai kesimpulan sehingga kesimpulan akhir yang didapat dapat lebih akurat.

\section{PEMBAHASAN}

Diskusi mengenai hak beragama di Indonesia merupakan tema yang sangat menarik. Mengapa menarik ? Pertama, seperti dalam beberapa hal umat Islam sebagai kelompok agama mayoritas masih merasa menjadi minoritas dalam akses politik maupun ekonomi di republik ini. Bagi sebagian kelompok, kondisi perpolitikan di Indonesia masih belum sepenuhnya merepresentasikan kepentingan umat Islam. Sebagian kelompok dalam Islam menggunakan logika bahwa mayoritas karena perannya yang "lebih" terhadap bangsa ini, seharusnya juga diperlakukan secara "lebih". Oleh karena itu, sistem politik yang sesuai menurut kelompok ini adalah politik afirmasi dan representasi. Penguatan dan perwakilan dari umat Islam untuk sebanyak mungkin mengisi posisi-posisi startegis di negeri ini baik pada arena politik maupun ekonomi.

Kedua, muncul gejala menguatnya kembali politik identitas yang acap meminggirkan kelompok lemah dan minoritas. Demokrasi kerap dimaknai sebagai mayoritanisme. Otoritas 
mayoritas sebagai pengelola dan penentu kebijakan merupakan kecenderungan umum di sejumlah daerah di Indonesia. Melalui pintu demokrasi, berkembang tuntutan, aspirasi dan warna kebijakan politik yang ditentukan dan dikendalikan oleh mayoritas (majority rule). Karena ditentukan oleh logika mayoritas, akibatnya di sejumlah daerah banyak muncul kebijakan yang kurang berpihak bahkan meminggirkan keberadaan kelompok minoritas.

Pengakuan dan penghormatan terhadap hak beragama oleh kelompok mayoritas bukan perkara mudah. Sebagai kelompok mayoritas, umat muslim Indonesia kurang merasakan menjadi kelompok minoritas. Kecuali di beberapa wilayah di mana umat Islam sebagai minoritas seperti di Bali, NTT, atau wilayah Papua, secara umum umat Islam Indonesia tidak memiliki beban psikologis seperti yang dirasakan minoritas. Apalagi jika dibandingkan dengan keberadaan umat muslim di negara-negara yang mayoritas berpenduduk non-muslim. Apa yang dirasakan umat Islam Indonesia tentu tidak sama dengan yang dirasakan umat muslim di wilayah lain seperti Eropa, Australia dan Amerika. Problem relasi mayoritas-minoritas sebetulnya adalah problem khas minoritas. Maka jika umat Islam yang mayoritas harus berbicara tentang hak-hak minoritas tentu hal ini menjadi sesuatu yang menantang (challenging).

Ketiga, munculnya serangkaian sikap radikalisme dan tindak kekerasan yang mengatasnamakan agama, kerap menjadikan Islam sebagai tertuduh. Hal ini jelas merusak citra posisitif Islam sebagai agama yang cinta damai.

Keempat, pola hubungan damai yang dikembangkan oleh Islam di Indonesia pada gilirannya akan berkontribusi bagi kelangsungan Negara Kesatuan Republik Indonesia (NKRI) sekaligus dapat disumbangkan bagi penciptaan peradaban dunia yang lebih damai. Di saat sebagian negara-negara Barat menaruh curiga dan pada tingkat tertentu phobia terhadap Islam atau negara-negara Timur Tengah, sebetulnya Barat menaruh harapan akan hadirnya wajah Islam yang damai dari Indonesia. Wajah Islam Indonesia diakui sebagai Islam moderat yang lebih toleran terhadap perbedaan.

Bertolak dari sejumlah alasan di atas, maka melihat peran Negara dalam pemperlakukan semua pemeluk agama secara proporsional (adil) sangatlah menarik dan penting. Apalagi jika dikaitkan dengan pengembangan demokrasi dan terjaminnya HAM yang telah menjadi pilihan bangsa ini. Salah satu prasyarat sistem demokrasi adalah penghargaan dan perlindungan terhadap semua kelompok secara adil.

Demokrasi menganut prinsip kesamaan dan keadilan bagi semua warga negara. Setiap warga negara dijamin hak-haknya termasuk kebebasan dalam beragama atau berkeyakinan (freedom of religion or belief). Salah satu hak dasar manusia yang pemenuhannya tidak dapat ditangguhkan atau dikurangi dalam situasi dan kondisi apapun (non-derogable rights).

Persoalannya adalah bagaimana memadukan antara kepentingan mayoritas dan melindungi hak-hak minoritas. Atau dengan menggunakan istilah Jon Elster, bagaimana membangun keseimbangan antara majority rule dan individual rights. Menjawab pertanyaan di atas tentu bukan perkara mudah. Persoalan relasi mayoritas dan minoritas tidak cukup hanya berkutat pada salah satu di antara keduanya. Ia melibatkan dua hal penting; yaitu kesiapan kultur mayoritas sebagai subyek utama dan konstitusi negara.

\section{Kebijakan Negara terhadap Kelompok Minoritas}

Sebagai bangsa yang terdiri dari banyak agama, suku, ras dan adat istiadat, ragam kelompok keyakinan di Indonesia dengan sendirinya juga berkembang. Ada minoritas etnis, minoritas ras, dan minoritas agama. Di dalam kelompok agama sendiri ada minoritas aliran atau madzhab, minoritas penganut kepercayaan, dan lain-lain. Dari sekian banyak kelompok minoritas tersebut, keberadaan minoritas agama adalah yang paling problematik terutama terkait dengan kebebasan dalam beribadah sesuai agama dan keyakinannya masing-masing.

Dalam dua dekade terakhir ini, keberadaan kelompok-kelompok minoritas ini sering mendapat perlakuan yang kurang diharapkan. Meskipun secara konstitusional negara memberi jaminan terhadap keberadaan kelompok minoritas, namun faktanya banyak kelompok yang tidak dapat leluasa mengamalkan dan mengembangkan agama dan keyakinan mereka. Hingga saat ini, sejumlah pelanggaran terhadap aktivitas beragama dan berkeyakinan masih menghisai wajah buruk hubungan antar mayoritas dan minoritas. Ironisnya, munculnya perlakuan diskriminatif ini justeru dilakukan oleh negara melalui penerbitan serangkaian peraturan yang kemudian dijadikan justifikasi oleh kelompok mayoritas untuk memusuhi dan meminggirkan kelompok minoritas. Perlakuan seperti ini terjadi dalam beberapa bentuk seperti: klaim penyesatan terhadap aliran keagamaan dan kepercayaan, penutupan tempat ibadah, larangan mengembangkan dan mendakwahkan keyakinan, hingga pembatasan hak-hak politik dan akses ekonomi.

Dasar hukum yang kerap dijadikan alasan pembenar bagi sebuah kelompok dalam menghakimi kelompok lainnya adalah keputusan negara melalui Menteri Agama, Menteri Dalam Negeri, dan Jaksa Agung yang mengeluarkan Surat Keputusan Bersama (SKB) tertanggal 9 Juni 2008 yaitu terdapat enam butir isi SKB ini: (1) Memberi peringatan dan memerintahkan untuk semua warga negara untuk tidak menceritakan, 
menafsirkan suatu agama di Indonesia yang menyimpang sesuai UU No 1 PNPS 1965 tentang pencegahan penodaan agama; (2) Memberi peringatan dan memerintahkan bagi seluruh penganut, pengurus Jemaat Ahmadiyah Indonesia (JAI) sepanjang menganut agama Islam agar menghentikan semua kegiatan yang tidak sesuai dengan penafsiran Agama Islam pada umumnya. Seperti pengakuaan adanya Nabi setelah Nabi Muhammad saw.; (3) Memberi peringatan dan memerintahkan kepada anggota atau pengurus JAI yang tidak mengindahkan peringatan tersebut dapat dikenai sanksi sesuai peraturan perundangan; (4) Memberi peringatan dan memerintahkan semua warga negara menjaga dan memelihara kehidupan umat beragama dan tidak melakukan tindakan yang melanggar hukum terhadap penganut JAI; (5) Memberi peringatan dan memerintahkan kepada warga yang tidak mengindahkan peringatan dan perintah dapat dikenakan sanksi sesuai perundangan yang berlaku; dan (6) Memerintahkan setiap pemerintah daerah agar melakukan pembinaan terhadap keputusan ini. Meskipun SKB ini hanya meyatakan pelarangan organisasi JAI, dan tidak menyuruh melakukan tindakan anarkitis, tetapi massa yang marah tidak lagi mempedulikan hal tersebut.

Kebijakan Negara tersebut bukan hanya menimpa kelompok yang dianggap menyimpang saja, produk kebijakan yang dikeluarkan negara juga dapat berimbas pada pemberangusan keberadaan kelompok penghayat kepercayaan dan sejumlah agama lokal. Seperti diketahui jumlah kelompok seperti ini di Indonesia sangat banyak semisal Sunda Wiwitan (Kanekes, Banten), Agama Djawa Sunda (kuningan, Jawa Barat), Buhun (Jawa Barat), Kejawen (Jawa Tengah dan Jawa Timur), Parmalim (Sumatera Utara), Kaharingan (Kalimantan), Tonaas Walian (Minahasa Sulawesi Utara), Tolotang (Sulawesi Selatan), Wetu Telu (Lombok), Marapu (Sumba) Budi Luhur, Purwoduksino, Naurus (Pulau Seram, Maluku), Pahkampetan, Bolim, Basora, Samawi dan masih banyak lagi.

Keberadaan kelompok-kelompok penghayat kepercayan di atas tergusur akibat pemberlakuan Penetapan Presiden No. 1/ PNPS/ 1965 tentang Pencegahan Penyalahgunaaan dan/atau Penodaan Agama. Dengan keluarnya PP yang dikukuhkan oleh rezim Orde Baru menjadi UU No.1/PNPS/1965 tersebut, maka kelompokkelompok agama asli nusantara ini kemudian diminta untuk masuk kedalam salah satu agama resmi yang diakui negara yaitu Islam, Kristen Katolik, Kristen Protestan, Hindu, Budha atau Konghucu. Para penganut Kaharingan di Kalimantan misalnya terpaksa harus berafiliasi dengan Hindu dan komunitas Wetu Telu di Lombok harus konversi kedalam Islam.

Jauh sebelumnya, model pengawasan terhadap praktik keagamaan dan kepercayaan masyarakat seperti ini sejatinya telah dilakukan negara di antaranya melalui pembentukan Pengawas aliran Kepercayaan Masyarakat (PAKEM). Sesuai namanya lembaga ini memiliki otoritas untuk mengawasi dan "memata-matai" aktifitas penganut kepercayaan yang tidak menjadi bagian dari agama resmi. Di bawah Departemen Agama (sekarang Kementrian Agama), lembaga PAKEM menurut Mulder menjadi semacam watch dog bagi gerakangerakan spiritual yang melawan Islam.

Kehadiran lembaga PAKEM terbukti sangat efektif dalam memantau dan mengawasi aliran kepercayaan, apalagi semenjak dikeluarkannya Surat Edaran Departemen Kejaksaaan Biro Pakem Pusat NO. 34/Pakem/S.E./61, pendirian lembaga ini kemudian meluas hingga tingkat propinsi dan kabupaten. Praktis dengan jangakuannya yang meluas seperti itu, lembaga PAKEM menjadi kepanjangan tangan negara dalam mengontrol aktifitas warganya dalam soal-soal yang sebetulnya masuk dalam wilayah privat atau domestik.

Dari kronologis tersebut, sepertinya Negara semakin sistematis dalam mengeluarkan kebijakan yang berisi perlindungan terhadap keberadaan agama resmi, agama yang diakui Negara. Pada tahun 1978, MPR menetapkan TAP MPR NO. IV/MPR/1978 tentang Garis-garis Besar Haluan Negara, di mana secara eksplisit disebutkan bahwa "aliran kepercayaan terhadap Tuhan Yang Maha Esa bukan merupakan agama". Berdasar pada TAP MPR ini Menteri Agama mengeluarkan Intruksi no. 4 dan 14 tahun 1978 yang bersisi kebijakan inti mengenai aliran kepercayaan. Melalui serangkai aturan seperi ini, negara memang secara sistematis telah meminggirkan kelompok-kelompok minoritas penganut kepercayaan yang dianggap belum beragama.

Dari berbagai kebijakan yang telah dibuat, tampaknya perlakuan negara terhadap minoritas masih belum sepenuhnya mencerminkan prinsipprinsip demokrasi yang menjunjung tinggi kesetaraan. Prinsip kesetaraan warga negara belum sepenuhnya terakomodir dalam produk perundang-undangan di Indonesia. Demi alasan menjaga stabilitas, kebijakan yang muncul lebih berorientasi pada kepentingan mayoritas. Untuk itu sekali lagi perlu dirumuskan kebijakan yang tepat serta mampu mengayomi dan melindungi semua warganya.

Berikutnya adalah bagaimana dengan implementasi kebijakan negara tentang kebebasan beragama dan berkeyakinan? Dalam implementasi kebijakan di lapangan, aparat negara juga belum sepenuhnya melindungi minoritas. Aparat kerap kali dipaksa mengikuti selera mayoritas. Negara gamang dalam menegakkan wibawanya untuk berdiri di tengah dan bertindak memberi pengayoman kepada seluruh warganya. Banyak kasus yang 
memperlihatkan betapa aparat negara harus tunduk di bawah tekanan kelompok-kelompok tertentu yang kerap memaksakan kehendaknya atas nama mayoritas. Bahkan demi memenuhi selera mayoritas, tidak jarang yang terjadi adalah tindakan mengorbankan korban (victimizing victims) yang bisa mendukung negara demokrasi.

Selain kasus penyesatan, perlakuan yang sering dirasakan oleh berbagai kelompok keagamaan adalah tindakan pelarangan pendirian dan penutupan rumah ibadah. Tempat beribadah memang salah satu tempat favorit yang menjadi sasaran amarah massa. Dalam banyak kasus penutupan dan penyegelan tempat ibadah terkadang merembet kepada fasilitas lain misalnya sekolah, sekretariat yayasan yang dianggap memiliki afiliasi terhadap agama tertentu. Tempat beribadah umat minoritas Kristen adalah yang paling sering mendapatkan perlakuan semacam ini. Data yang dilansir media masa menyebutkan bahwa di tahun 2009 dari 35 kali kekerasan terhadap kebebasan beragama, 28 kali terkait dengan kelompok Kristen. Penyebabnya bisa bermacam-macam. Mulai dari alasan izin pendirian tempat ibadah yang dinilai belum lengkap, ketiadaan persetujuan warga sekitar atas keberadaan tempat tersebut, hingga alasan lain seperti menganggu ketertiban umum. Namun dibalik alasan-alasan yang dimunculkan, sebagian kalangan menyatakan bahwa agresifitas penyebaran agama atau misi misionaris yang terlanjur melekat dalam agama Kristen rupanya menyebabkan banyak umat Islam merasa khawatir terhadap perluasan agama tersebut di negeri ini.22 Ada kegelisahan di kalangan umat Islam akan kehilangan jamaah akibat aktifitas kristenisasi.

Kontestasi simbol agama memang bukan hanya karakteristik Islam. Hal ini sangat tergantung pada kondisi dan karakteristik daerah masing-masing. Pada daerah-daerah di mana Islam sebagai mayoritas, maka isu-isu keislaman yang akan ditonjolkan. Sementara pada daerahdaerah seperti di wilayah NTT atau Papua di mana warga Kristen dominan maka identitas Kristen yang menonjol. Demikian halnya ketika di Bali, maka simbol kehinduan yang mengemuka.

Penguatan identitas keagamaan seperti ini terkadang bersaing dengan identitas etnis, isu pribumi (warga asli) dan non-pri (warga pendatang). Isu minoritas pendatang yang sukses dengan mayoritas pribumi yang tertindas juga kerap mengemuka pada moment-moment politik di daerah. Narasi-narasi masa lalu baik yang berupa kejayaan pribumi maupun ketertindasan (grievances) sengaja dibangkitkan untuk mendukung menyatukan massa yang mengambang.

\section{KESIMPULAN}

Dalam negara yang menganut sistem demokrasi, kedudukan setiap warga negara adalah sederajat di mata hukum. Sebagai konsekuensi logis dari pilihan sistem ini, negara berkewajiban memberikan dan melindungi hakhak setiap warganya tanpa adanya diskriminasi. Negara harus berdiri kuat dan netral untuk menjamin bahwa suatu kelompok masyarakat tidak boleh menguasai maupun mengintimidasi kelompok lainnya. Mayoritas tidak boleh mengontrol, menindas dan menyingkirkan keberadaan kelompok minoritas. Atas nama konstitusi, kekuasaan negara juga tidak seharusnya dikendalikan oleh dan untuk memenuhi kepentingan dan selera kelompok tertentu namun harus untuk kemaslahatan bersama.

Undang-undang Negara Indonesia telah menjamin hak dan kebebasan setiap warganya untuk beragama sesuai keyakinannya sendiri. Oleh karena itu, maka selayaknyalah orang-orang yang duduk di legislatif dan eksekutif untuk senantiasa menjaga kebebasan beragama setiap warganya tersebut tanpa melihat ideologi yang dianutnya.

Untuk menghapus praktik-praktik diskriminatif dan ketidakadilan, maka diperlukan dua jalur upaya sekaligus; perjuangan politik kesetaraan dan penguatan kapasitas dan pemahaman multikulturalisme atas nilai-nilai demokrasi. Upaya pertama merupakan advokasi atas sejumlah kebijakan negara yang masih dirasa belum adil. Beberapa produk undang-undang yang kurang selaras dengan semangat UUD 1945 dan perkembangan dunia modern sudah selayahnya ditinjau kembali. Sedangkan upaya kedua dimaksudkan untuk memperkuat kesadaran umat mayoritas untuk lebih mengembangkan nilai-nilai kesetaraan, kebebasan, humanistik, cinta tanah air dan toleransi terhadap keragaman. Apabila hal-hal mulia ini berhasil dikembangkan dan diimplementasikan oleh seluruh umat maka akan bermanfaat tidak hanya bagi konsolidasi demokrasi di negeri ini, tetapi juga akan semakin meneguhkan bangsa dan Negara.

\section{DAFTAR PUSTAKA}

Anwar, M Syafi'i.2009."Ketika Pluralisme diharamkan dan Kebebasan Berkeyakinan Dicederai" dalam Elza Peldi Taher (ed.), Merayakan Kebebasan Beragama: Bungai Rampai 70 Tahun Djohan Effendi, Jakarta: ICRP dan Kompas

Elster, Jon.1993."Majority Rule and Individual Rights", dalam Stephen Shute and Susan Hurley. (eds.), On Human Rights, New York: Basic Books

Hardiman, F. Budi.2002."Pengantar: Belajar dari Politik Multikulturalisme" dalam Will Kymlika, Kewargaan Multikultural. Teori Liberal mengenai Hak-hak Minoritas, Jakarta: Pustaka LP3ES Indonesia 
Hasani, Ismail dan Bonar Tigor Naispospos (eds.)2011.Negara Menyangkal Kondisi Kebebasan Beragama/Berkeyakinan di Indonesia Tahun 2010, Jakarta: Pustaka Masyarakat Setara

Huntington, Samuel P.1997. The Chlas of Civilization. Remarking of The world Order, New York: Simon and Schuster

Mulder, Niels.1983. Kebatinan dan Hidup Seharihari Orang Jawa: Kelangsungan dan Perubahan Kulturil, Jakarta: Gramedia

Panggabean, Samsul Rizal dan Ihsan Ali Fauzi.2011. Polisi, Masyarakat dan Konflik Keagamaan di Indonesia, Jakarta: Paramadina

Samuel P. Huntington.1997. The Chlas of Civilization. Remarking of The World Order, New York: Simon and Schuster
Suaedy, Ahmad dan Rumadi (ed.).2007. Politisasai Agama dan Konflik Komunal: Beberapa Isu Penting di Indonesia,. Jakarta: The Wahid Institute

Trisno S. Sutanto.2006. "Politik Kesetraan" dalam Elza Peldi Taher (ed), Merayakan Kebebasan Beragama

Umam, Fawaizul, "Menolak Kekerasan, Menenggang Keragaman: Refleksi atas Kasus Kekerasan terhadap Ahmadiyah" Jurnal Tasamuh Vol 4, Nomor 1 Desember 2006.

\section{Sumber-sumber lain}

http://www.metrotvnews.com/read/newsvideo/ http://www.asianews.it http://www.thejakartapost.com/news 